RAD Conference Proceedings, vol. 3, pp. 174-180, 2018

ISSN 2466-4626 (online) | DOI: 10.21175/RadProc.2018.38

www.rad-proceedings.org

\title{
USE OF THE NEUTRON ACTIVATION ANALYSIS TECHNIQUE TO DETERMINE HEAVY METALS IN NICOTIANA TABACUM SOLANACEAE
}

\author{
Tufic Madi Filho', ${ }^{*}$, Elson Barros Ferreira ${ }^{2}$, \\ Maria da Conceição Costa Pereira ${ }^{1}$, José Roberto Berretta ${ }^{1}$ \\ ${ }^{1}$ Instituto de Pesquisas Energéticas e Nucleares, São Paulo, Brazil \\ ${ }^{2}$ Secretaria da Educação do Estado de São Paulo, São Paulo, Brazil \\ ${ }^{3}$ Software Engineering Research Group, Paulista University, UNIP, Campus Tatuapé, São Paulo, Brazil
}

\begin{abstract}
Tobacco addiction has been mentioned as a leading cause of preventable illnesses and premature disability since tobacco smoking is the main cause of lung cancer and one of the factors that most contribute to the occurrence of heart diseases, among others. The herbaceous species Nicotiana tabacum is a plant of the solanaceae family used for tobacco production. Some authors have conducted research about heavy metals and the toxicity of tobacco. It is, frequently, found in low concentrations in the ground, superficial and underground waters, even though they do not have environmental anthropogenic contributions. However, with the increase of industrial activities and mining together with the agrochemical use of contaminated organic and inorganic fertilizers, an alteration of the geochemical cycle occurs. As a consequence, the natural flow of that materials increases and release into the biosphere, where they are often accumulated in the superior layer of the ground, accessible to the roots of the plants. During planting and plant development, fertilizers and insecticides, including organochlorines and organophosphates, are used; consequently, the smoke from cigarette smoking presents various toxic substances, including heavy metals, such as Chromium (Cr), Manganese (Mn) and Antimony (Sb). Elements studied in this work. The procedures for the preparation of the samples were carried out in our laboratories and submitted to irradiation with thermal neutrons at IPEN/CNEN-SP, in the IEA-R1 research reactor. The irradiated material was, then, analyzed by gamma spectrometry, using a high purity germanium detector (HPGe).
\end{abstract}

Key words: Nicotiana tabacum, Chromium, Manganese, Antimony, NAA

\section{INTRODUCTION}

The spread of tobacco in the early twentieth century caused its consumption to increase during the World War II, reaching its peak in the 1950's and 1960's. There was a slight decline in only a few countries in the 1970's, but, problems related to the exposure and use of tobacco and its derivatives continue to occur and, since it is a public health issue, smoking and its risks continue to merit the attention of science [1]. Currently, several countries question smoking, such as Ireland, England, Japan and Israel.

In Brazil, the anti-smoking law started being implemented in states, as in the state of São Paulo with law number 13.541, dated May 7, 2009. In 2014, the Federal Law 12,546 came into force, prohibiting smoking of cigarillos, cigars, pipes, hookahs and other products in places of collective use, public or private, such as halls and corridors of condominiums, restaurants and clubs. This situation stimulated the development of this work.

Smoking has been ranked as one of the leading causes of preventable illnesses and premature disabilities. It is known that smoking is the main cause of lung cancer and one of the factors that most contribute to the onset of heart diseases, among others [2]. Passive smoking is already considered the third leading cause of inevitable death in the world, behind active smoking and excessive consumption of in situ alcoholic beverages [3], involving both inhalation of primary and secondary stream smoke and exhaled smoke [4].

The chemical constitution of the smoke produced in the combustion process is complex, containing several types of components, several dozens of them being carcinogenic.

Carbon monoxide, nitrogen dioxide, formaldehyde, polycyclic aromatic hydrocarbons, metallic and radioactive elements are among the gases that constitute tobacco [2], [4], [5]. The particulate fraction of the so-called tar smoke contains nicotine and hydrocarbons and, also, traces of metals found in the gas phase, making the particulate fraction an important source of air pollution, including indoor air pollution, due to the presence of these substances [4], [5], [6], [7].

Tobacco (Nicotiana tabacum L.) destined to Brazilian industries is cultivated mainly in southern

*tmfilho@usp.br, tufic.madi@gmail.com 
T.M. Filho, et al., Determining Heavy Metals In Nicotiana Tabacum Solanaceae, RAD Conf. Proc., vol. 3, 2018, 174-180

Brazil (Figure 2), comprising three states, Rio Grande do Sul, Santa Catarina and Paraná [8], [9]. The cultivation of tobacco is one of the main agricultural activities in Rio Grande do Sul, the state with the largest planted area (180,00o ha), where Virginia and Burley types are grown, accounting for $78.2 \%$ and $20.5 \%$ of the area, respectively, with the remainder being common tobacco [10], [11]. ]. Figures 1 and 2 present photographs taken during this work.

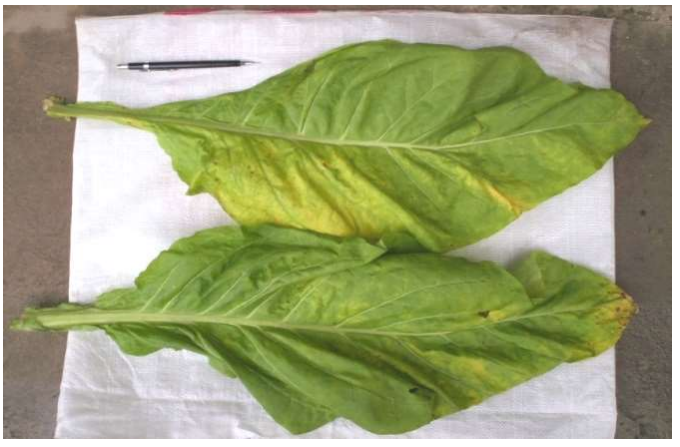

Figure 1. Leaf of Nicotiana tabacum L.

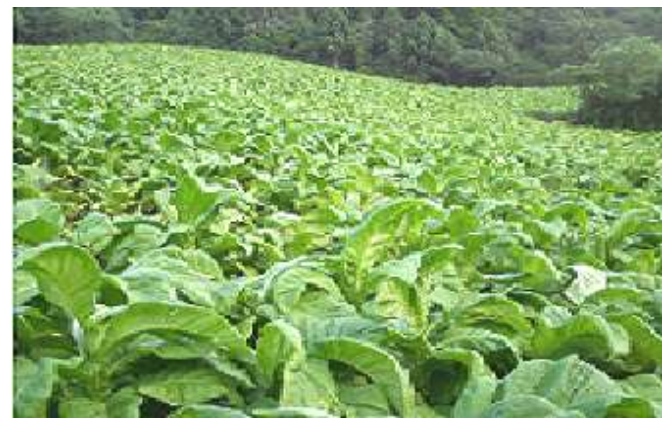

Figure 2. Tobacco Plantation

\section{OвJECTIVE}

The objective of this work was to perform a comparative analysis of Bromine, Manganese and Antimony contents in in natura leaves and in the industrially processed tobacco in order to verify whether there is transference of the elements between the in natura leaves and those which are industrially processed, with either a decrease or an increase in the process of industrialization, due to the industrial processing chemistry. For this experiment were used tobacco and industrialized materials totally obtained in Rio Grande do Sul.

\subsection{Chemical Composition of Tobacco}

The tobacco leaf may contain about 500 different constituents, depending on the growing region, soil, drying and storage [12]. The leaf combustion in the form of smoke has a complex chemical constitution, presenting various types of components: gases such as carbon monoxide, nitrogen dioxide, formaldehyde, polycyclic aromatic hydrocarbons, as well as metallic and radioactive elements. The particulate fraction of the tobacco (tar) contains nicotine, hydrocarbons and trace elements of less volatile metals that are also found in the gas phase [4], [6].

These constituents have some influence on human behavior and health. The substances analyzed in this paper are described below:

\subsection{Bromine $(\mathrm{Br})$}

Bromine belongs to the group of nonmetals (halogens) and it is the only liquid element among them; it is very volatile at room temperature. It has, among its main physical and chemical properties, the atomic weight of 79.90 , the melting point of $\left(-7.2^{\circ} \mathrm{C}\right)$, and the boiling point of $58.8^{\circ} \mathrm{C}$. It may present different oxidation states, the most common are: 1-, 1+, $3^{+}$and $5^{+}[13]$.

Bromine occurs in the form of salts diffused in some rocks and saline waters from natural sources and it is a part of the seawater, containing about $85 \mathrm{ppm}$ in the form of bromine (Br-) [14].

This element has application in the manufacture of sprays, non-flammable agents, products for water purification, colorants, photography (silver bromide, $\mathrm{AgBr}$ ), disinfectants, insecticides and others. Methyl bromide organic compound, $\mathrm{CH}_{3} \mathrm{Br}$, has application as a pesticide, but, it presents the inconvenient consequence of its effect on the ozone layer. Although it occurs in a smaller amount than those of chlorine, bromine atoms are, as determined, more effective than chlorine atoms in the ozone layer depletion mechanisms [15]. It is found at trace levels in humans, although its functions are not known yet, since one of the essential elements and some of its compounds are used in the treatment of epilepsy and as sedatives [16]. However, bromine is highly toxic and, in small amounts (10 ppm), either inhaled or through the dermis, may cause health problems, leading to death. It is also very irritating to the eyes and throat and causes painful inflammations in contact with the skin [16].

\subsection{Manganese (Mn)}

It is an essential chemical element to all life forms, with both structural and enzymatic functions [17], [18], [19]. It presents seven states of oxidation, the main ones are: Mn2+, Mn3+, Mn4+ and Mn7+. Elemental manganese has a specific density of 7.21 to $7.4 \mathrm{~g} / \mathrm{cm}^{3}$, depending on the allotropic form, a melting point of $1260^{\circ} \mathrm{C}$, a boiling point of $1962^{\circ} \mathrm{C}$ (OGA, 2003). Oxides, carbonates and silicates of manganese are the most abundant compounds in nature and are characterized by being insoluble in water [12].

Among the main industrial applications causing the occurrence of manganese exposure are: the manufacture of safe phosphorus, dry batteries, nonferrous alloys containing copper and nickel, porcelain enamel, fertilizers, fungicides, animal feeding, welding electrodes, magnets, catalysts, glasses, paint, electrical materials and pharmaceuticals (chlorides, oxides, and manganese sulphates), with the most significant forms of exposure occurring by manganese fumes and dust [12].

According to Etges (2002) [20], it is common to find high concentrations of manganese in soils and sediments where the cultivation of the tobacco plant 
T.M. Filho, et al., Determining Heavy Metals In Nicotiana Tabacum Solanaceae, RAD Conf. Proc., vol. 3, 2018, 174-180

occurs, as the content of this element is very high in the basaltic rocks that gave origin to the soils of the cultivation regions. There is, also, the possibility of residues coming from insecticides, fungicides, pesticides and fertilizers applied in fumigant properties.

\subsection{Antimony (Sb)}

Antimony in its trivalent state (Sb III) is considered a clastogenic agent, but not mutagenic, and this species is responsible for the toxic effects. Studies on antimony have not shown the carcinogenicity of this metal in humans, although antimony trioxide $\left(\mathrm{Sb}_{2} \mathrm{O}_{3}\right)$ is suspected to be a possible carcinogen. The available information on the toxicological aspects of antimony comes from studies of pharmacological antimonybased organic compounds [21].

\section{MATERIALS AND Methods}

In the development of this work, the following items were used: Gamma Spectrometry System composed by an HPGe of $30 \%$ of relative efficiency for the measurement of the material powders irradiated in the IEA-R1 reactor, under a thermal neutron flux $[14,15]$.

The Nuclear Research Reactor IEA-R1 of the Instituto de Pesquisas Energéticas e Nucleares is a swimming pool type reactor, designed by "Babcock \& Wilcox Company," with its first criticality on September 16, 1957.

For the application of Neutron Activation Analysis (NAA), it has a Pneumatic Transfer System to transport and transfer materials to be irradiated for a maximum time $=5$ minutes, and an irradiation system element for a long time irradiation. Both systems were used in this work.

Samples of leaves, stems, roots of Nicotiana Tabacum Solenacea plant and local soil in the superficial layer (0-5 and $15-20 \mathrm{~cm}$ ) collected in the area of Vale do Rio Pardo, municipal district of Boqueirão do Leão (RS) Figures 1, 2. All the samples were conditioned in atoxic PVC plastic transparent film packages for transportation. The leaves were dried in a greenhouse $\left(50-60^{\circ} \mathrm{C}\right)$, the roots and the stems were washed in running water to eliminate soil remains and, later, submitted to evaporation in the greenhouse $\left(50^{\circ} \mathrm{C}\right)$. The soil samples were air-dried and submitted to granulometric separation (ABNT, NBR 7181/1984) $[12,13]$. The leaves, roots and stems were milled and transferred to the heater-muffle in porcelain crucibles with temperature gradient of up to $500^{\circ} \mathrm{C}$. The resulting material was transferred to polyethylene capsules to be submitted to irradiation. Table 1 shows the number and respective mass of the samples.

Table 1. Samples "in natura" and respective mass

\begin{tabular}{|c|c|}
\hline Leaves "In Natura" & Mass (g) \\
\hline 1A & 0.3064 \\
\hline $2 \mathrm{~B}$ & 0.3053 \\
\hline 3C & 0.3013 \\
\hline $4 \mathrm{D}$ & 0.3027 \\
\hline $5 \mathrm{E}$ & 0.3055 \\
\hline
\end{tabular}

\subsection{Preparation of Synthetic Standards}

For the qualitative and quantitative comparison of the chemical elements to be determined in in natura samples and in the ashes, synthetic standards were prepared from the dry weighing stage, in analytical scales (SARTORIUS, BP $210 \mathrm{~S}$ ), with masses of the respective analytical compounds (PA): Primary standard, Antimony trioxide $\left(\mathrm{Sb}_{2} \mathrm{O}_{3}\right)$ primary standard, Copper sulphate $\left(\mathrm{CuSO}_{4} 5 \cdot \mathrm{H}_{2} \mathrm{O}\right)$, Powdered metal zinc and GYP-D standard, packed in eppendorfs, composition of the patterns characterized according to (Table 2):

Table 2. Composition of synthetic patterns

\begin{tabular}{|c|c|c|c|}
\hline \multicolumn{5}{|c|}{ MIX Pattern } \\
\hline Pattern & $\begin{array}{c}\text { copper } \\
(\mathrm{g})\end{array}$ & $\begin{array}{c}\text { zinc } \\
(\mathrm{g})\end{array}$ & antimony $(\mathrm{g})$ \\
\hline MIX-52210 & 0.1081 & 0.1129 & 0.1022 \\
\hline MIX-52310 & 0.1089 & 0.1195 & 0.1060 \\
\hline \multicolumn{5}{|c|}{ GYP-D Pattern } \\
\hline Padrão & $\begin{array}{c}\text { Barium } \\
(\mu \mathrm{g} / \mathrm{g})\end{array}$ & $\begin{array}{c}\text { Manganese } \\
(\mu \mathrm{g} / \mathrm{g})\end{array}$ & $\begin{array}{c}\text { Bromine } \\
(\mu \mathrm{g} / \mathrm{g})\end{array}$ \\
\hline GYPD-1 & 53.7 & 100.4 & 0.65 \\
\hline \multicolumn{5}{|c|}{ Barium Pattern } \\
\hline \multicolumn{2}{|c|}{ Battern } & \multicolumn{3}{c|}{0.4952} \\
\hline A1BA0509 & $\mathrm{g})$ \\
\hline
\end{tabular}

\subsection{Activation Analysis with Neutrons (AAN)}

AAN is a nondestructive method of analysis that allows, in many cases, to determine the concentrations of 20 to 40 elements in a single sample. It consists of a neutron bombardment in a given material, followed by the measurement of the induced radioactivity. In general, irradiation is performed with thermal or epithermal neutrons and the resulting radioactivity is measured using gamma ray spectrometry emitted by each radioisotope.

The isotopes produced in the activation process have their own emission characteristics (half-life and particle energy or gamma radiation emitted) and it is possible to make quantitative determinations of the concentration by comparison with standards or by the direct method. The elements are identified as a function of the emitted gamma energy and their quantity is determined by the areas of energy peaks related to activated patterns, together with the samples [22], [23].

For the AAN, a neutron source, usually a research reactor, an ultra-pure Ge type high energy (HPGe) detector and a Multichannel Analyzer (MCA), which provides the energy spectrum of the gamma rays emitted by the irradiated material, are required [22].

\subsection{Relative or Comparative Instrumental Method}

It is the most used method for the quantification of radionuclides. The samples and patterns of the element to be analyzed are irradiated simultaneously under the same neutron flux. Then, they are measured under the same counting conditions. The concentration of the element of interest is calculated by comparing the activity measured between the sample and the standard. It is important that both may have welldefined compositions - the standard needs to be made 
T.M. Filho, et al., Determining Heavy Metals In Nicotiana Tabacum Solanaceae, RAD Conf. Proc., vol. 3, 2018, 174-180

from the same sample material, irradiated and analyzed under the same conditions. The isotopic mass is determined from the ratio of the sample and standard activities. The relative analysis is not very satisfactory for "multi-element" samples since it is practically impossible to produce a "multi-element" pattern with all detectable elements having the precision, volume, size and shape equal to those of the sample. Reference materials that are certified as standards may be used. Although it is a simple method, it is destructive and requires the preparation of a standard sample set so that each element may be determined [24],[25].

\subsection{Absolute or Parametric Method}

Detectors are used to measure the flux of neutrons. The type of detector depends on the magnitude of the shock section, the neutron beam, the irradiation time and the manufacturing properties of the activation detector [22].

Homemade software (Figure 1) was developed to calculate the neutron thermal flux and the isotopic fraction in the sample in order to use the NAA absolute method.

This method waives the use of standards, making it economically viable. This occurs because the neutron flux is accurately established by means of neutron sources, such as: ${ }^{239} \mathrm{PuBe},{ }^{241} \mathrm{AmBe}$ or ${ }^{252} \mathrm{Cf}$, which generate a stable neutron beam as a function of the long half-life of the isotopes; nuclear research reactors are more commonly used for this purpose.

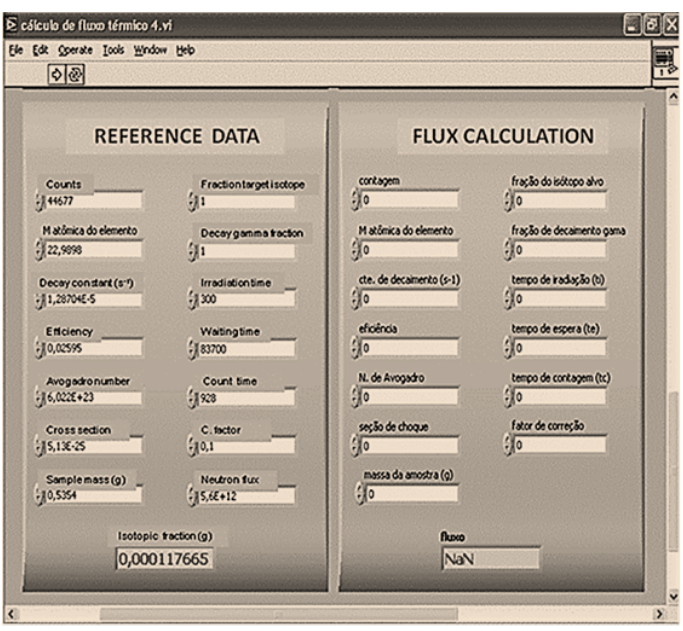

Figure 3. Screen of Homemade Software

\section{RESULTS}

Table 3 presents some information used in the isotope analyses detected in the irradiated samples.

Table 4 presents the fraction of isotopes found in the samples of ashes (industrialized) and in the in natura leaves, under conditions of irradiation in the reactor and in the pneumatic system from the absolute and comparative methods. Figure 4 presents the isotopic fraction detected in the samples irradiated according to the irradiation system.

\section{CONCLUSION}

Table 4 shows the values of the elements quantified by the absolute and comparative methods. Only manganese was quantified using the comparative method. It may be noted that there is little variation between the values detected by the two methods. By the absolute method, manganese was quantified only in $8 \mathrm{H}$ and $4 \mathrm{D}$ samples because, to analyze $6 \mathrm{~F}$ and $3 \mathrm{C}$ samples, a waiting time of, approximately, $48 \mathrm{~h}$ was required. Mn-56 ( $\left.\mathrm{t}_{1 / 2}\right)$ half-life is $2.58 \mathrm{~h}$, and, then, the activated manganese had already decreased when measurements were initiated.

Table 4 and Figure 4 show the fraction of the isotopes detected in the irradiated samples, according to the irradiation system. There are no established values of manganese in $3 \mathrm{C}, 6 \mathrm{~F}$ samples because it could not be observed with activation by the reactor. The same happens with the antimony in the $8 \mathrm{H}$ sample, activated by the pneumatic system. The bromine element is the only one that appears in all the samples, demonstrating that could be detect in the natural leaves and in the industrialized.

The comparative analysis of nicotine tabacum leaf samples and chopped tobacco ashes, using the AAN, allowed the identification of the presence of associated elements not only in the natural plant, but, also in the cigarette industrialized.

The presence of bromine in samples of "in natura" leaves may be related to the continued use of methyl bromide based anti-sprouting, as well as the use of rodenticides that possess this element in their chemical composition. It was, also, possible to identify the presence of bromine in the ash where, not only the transfer among the leaves and the processed tobacco occurred, but, also a considerable increase of this element was verified (Table 4 and Figure 4).

Although manganese is an essential element available in the soil and, therefore, naturally absorbed by the roots of the plants, this element is present in the "in natura" leaves and, in a greater amount, in the ashes, demonstrating not only the transfer but, also, an increase, possibly due to the additives applied in the process of cigarette industrialization (Table 4 and Figure 4). An excess of this element in the body may compromise the Central Nervous System (CNS) and lungs.

The antimony element was not identified in the leaf samples, but, its presence in the ashes demonstrated that this element starts composing the smoke from the process of cigarette industrialization (Table 4 and Figure 4). The antimony element presents, although with less toxicity, effects similar to those of arsenic, being able to produce harmful effects to the respiratory and cardiovascular system. 
T.M. Filho, et al., Determining Heavy Metals In Nicotiana Tabacum Solanaceae, RAD Conf. Proc., vol. 3, 2018, 174-180

Table 3. Data of the isotopes detected in the irradiated samples

\begin{tabular}{|c|c|c|c|c|c|c|c|}
\hline $\begin{array}{l}\text { Isotope } \\
\text { Target }\end{array}$ & $\begin{array}{l}\text { Isotope } \\
\text { Formed } \\
\text { Isotope }\end{array}$ & $\begin{array}{c}\text { Isotopic } \\
\text { Abundance } \\
\text { (\%) }\end{array}$ & $\begin{array}{c}\sigma \\
\text { (barn) }\end{array}$ & $\begin{array}{l}\text { Nuclear } \\
\text { Reaction }\end{array}$ & $\begin{array}{l}\text { Half- } \\
\text { Life } \\
\left(t^{1} 1 / 2\right)\end{array}$ & $\underset{(\mathrm{keV})}{\operatorname{Gamma} \text { Energy }}$ & $\begin{array}{c}\text { Gamma abundance } \\
\text { (\%) }\end{array}$ \\
\hline Mn-55 & Mn-56 & 100 & 13.2 & ${ }^{55} \mathrm{Mn}(\mathrm{n}, \mathrm{g})^{56} \mathrm{Mn}$ & $2.58 \mathrm{~h}$ & $\begin{array}{c}846.76 \\
1810.72 \\
2113.05\end{array}$ & $\begin{array}{l}98.87 \\
27.119 \\
14.34\end{array}$ \\
\hline $\mathrm{Sb}-121$ & Sb-122 & $57 \cdot 30$ & 0.055 & ${ }^{121} \mathrm{Sb}(\mathrm{n}, \mathrm{g}){ }^{122} \mathrm{Sb}$ & $64.8 \mathrm{~h}$ & $\begin{array}{l}564.24 \\
692.65\end{array}$ & $\begin{array}{c}69.30 \\
3.78\end{array}$ \\
\hline $\mathrm{K}-41$ & $\mathrm{~K}-42$ & 6.73 & 1.45 & ${ }^{41} \mathrm{~K}(\mathrm{n}, \mathrm{g}){ }^{42} \mathrm{~K}$ & $12.36 \mathrm{~h}$ & 1524.58 & 18.80 \\
\hline $\mathrm{Na}-23$ & $\mathrm{Na}-24$ & 100 & 0.513 & ${ }^{23} \mathrm{Na}(\mathrm{n}, \mathrm{g})^{24} \mathrm{Na}$ & $14.96 \mathrm{~h}$ & $\begin{array}{l}1368.60 \\
2754.00\end{array}$ & $\begin{array}{c}100 \\
99.94\end{array}$ \\
\hline $\mathrm{Br}-81$ & $\mathrm{Br}-82$ & 49.31 & 2.58 & ${ }^{81} \mathrm{Br}(\mathrm{n}, \mathrm{g})^{82} \mathrm{Br}$ & $353 \mathrm{~h}$ & $\begin{array}{c}554.35 \\
619.11 \\
698.37 \\
776.52 \\
827.83 \\
104.08 \\
1317.47 \\
1474.88\end{array}$ & \begin{tabular}{l|}
70.76 \\
43.44 \\
28.49 \\
83.54 \\
24.03 \\
27.23 \\
26.48 \\
16.32 \\
\end{tabular} \\
\hline
\end{tabular}

Table 4. Isotopic fraction of the detected element

\begin{tabular}{|c|c|c|c|c|}
\hline SAMPLE & & ELEMENT & \\
\hline & $\begin{array}{c}\text { Bromine } \\
\left(\mu \mathrm{g} . \mathrm{g}^{-1}\right)\end{array}$ & $\begin{array}{c}\text { Antimonium } \\
\left(\mu \mathrm{g} . \mathrm{g}^{-1}\right)\end{array}$ & $\begin{array}{c}\text { Manganese } \\
\left(\mu \mathrm{gg} \cdot \mathrm{g}^{-1}\right)\end{array}$ & $\begin{array}{c}\text { Mamparative } \\
\text { methods } \\
\left(\mu \mathrm{g} . \mathrm{g}^{-1}\right)\end{array}$ \\
\hline Manufactured & & & & \\
\hline $6 \mathrm{~F}$ (Reactor) & 5.768 & 5.9529 & & \\
\hline $8 \mathrm{H}$ (pneumatic) & 5.6174 & & 25.906 & 25.2 \\
\hline "in natura" Leaves & & & & \\
\hline 3C(Reactor) & 0.8869 & 0.1081 & & 16.2 \\
\hline 4D(pneumatic) & 0.7604 & 0.1298 & 11.5956 & \\
\hline
\end{tabular}

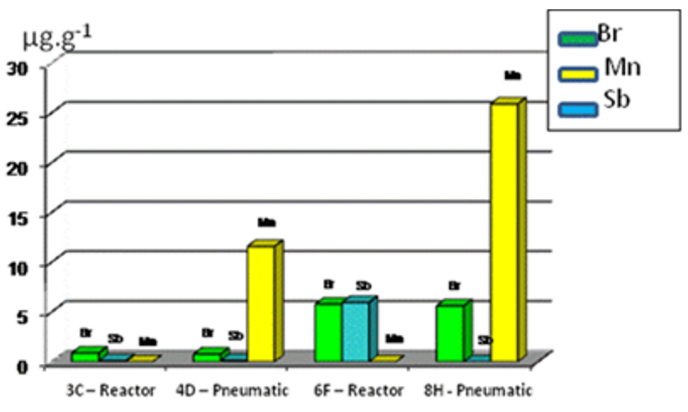

Figure 4. Isotopic Fraction of the Detected Elements

The presence of bromine in samples of "in natura" leaves may be related to the continued use of methyl bromide based anti-sprouting, as well as the use of rodenticides that possess this element in their chemical composition. It was also possible to identify the presence of bromine in the ash where not only the transfer among the leaves and the processed tobacco was verified but also a considerable increase of this element (Table 4 and Figure 4).

Although manganese is an essential element available in the soil and, therefore, naturally absorbed by the roots of the plants, this element is present in the "in natura" leaves and in a greater amount in the ashes, demonstrating not only the transfer but also an increase, possibly due to the additives applied in the process of cigarette industrialization (Table 8 and Figure 4). An excess of this element in the body may compromise the Central Nervous System (CNS) and lungs.

The antimony element was not identified in the leaf samples, but its presence in the ashes demonstrated that this element starts composing the smoke from the process of cigarette industrialization (Table 4 and Figure 4). The antimony element presents, although in less toxicity, effects similar to those of arsenic, being able to produce harmful effects to the respiratory and cardiovascular system. 
T.M. Filho, et al., Determining Heavy Metals In Nicotiana Tabacum Solanaceae, RAD Conf. Proc., vol. 3, 2018, 174-180

\section{REFERENCES}

1. A. C. P. R. Marques et al., "Consenso sobre o tratamento da dependência de nicotina," Rev. Bras. Psiquiatr. vol. 23, no. 4, pp. 200 - 214, Dec. 2001. (A. C. P. R. Marques et al., "Consensus on the treatement of nicotine addiction," Braz. J. Psyciatry, vol. 23, no. 4, pp. 200 - 214, Dec. 2001.) DOI: $10.1590 / \mathrm{S} 1516-44462001000400007$

2. M. C. Malcon, A. M. B. Menezes, M. Chatkin, "Prevalência e fatores de risco para tabagismo em adolescentes," Rev. Saúde Pública, vol. 37, no. 1, pp. $1-7$, Feb. 2003. (M. C. Malcon, A. M. B. Menezes, M. Chatkin, "Prevalence and risk factors for smoking among adolescents," Rev. Saúde Pública, vol. 37, no. 1, pp. $1-7$, Feb. 2003.)

DOI: 10.1590/Soo34-89102003000100003 PMid: 12488914

3. V. Carvalho, "A força e o horror do cigarro," Jornal Brasileiro Ecológico, vol. 2, no. 24, p. 19, 2004. (V. Carvalho, "The strenght and horror of cigarettes," Jornal Brasileiro Ecológico, vol. 2, no. 24, p. 19, 2004.)

4. C. Baird, Química ambiental, 2. ed., Porto Alegre, Brasil: Bookman, 2002. (C. Baird, Environmental Chemistry, 2nd ed., Porto Alegre, Brazil: Bookman, 2002.)

5. S. Landsberg, D. Wu., "The impact of heavy metals from environmental tobacco smoke on indoor air quality as determined by Compton suppression neutron activation analysis," Sci. Total Environ., vol. 173-174, pp. 323 - 324, Dec. 1995.

DOI: 10.1016/0048-9697(95)04755-7

6. Z. Harakeh et al., "Imitation of cigarette smoking: An experimental study on smoking in a naturalistic setting," Drug Alcohol Depend., vol. 85, n. 2-3, pp. $199-206,2007$.

DOI: 10.1016/j.drugalcdep.2006.06.006

7. V. B. M. Silva, M.E. Pereira, "Parâmetros hematológicos e toxicológicos em amostras de sangue de doadores fumantes," Rev. Bras. Anál. Clín., vol. 37, supl. 2, pp. 95 - 96, 2005. (V. B. M. Silva, M. E. Pereira, "Haematological and toxicological parameters in donor blood sampler from smokers," Rev. Bras. Anál. Clín., vol. 37, supp. 2, pp. 95 - 96, 2005.)

Retrieved from: http://www.rbac.org.br/wpcontent/uploads/2016/08/RBAC Vol.37 n2completa.pdf;

Retrieved on: Jul. 15, 2018

8. S. C. Correa et al., Anuário brasileiro do fumo, Santa Cruz do Sul, Brasil: Editora Gazeta, 2003. (S. C. Correa et al., Brazilian Tobacco Yearbook, Santa Cruz do Sul, Brazil: Editoria Gazeta, 2003.)

9. S. C. Correa et al., Anuário brasileiro do fumo, Santa Cruz do Sul, Brasil: Editora Gazeta, 2005. (S. C. Correa et al., Brazilian Tobacco Yearbook, Santa Cruz do Sul, Brazil: Editoria Gazeta, 2005.)

10. A. Specht et al., "Ocorrência de Rachiplusia nu (Guenée) (Lepidoptera: Noctuidae) em Fumo (Nicotiana tabacum L.) no Rio Grande do Sul, Brazil," Neotrop. Entomol., vol. 35, no. 5, pp. $705-706$, Sep-Oct. 2006. (A. Specht et al., "Occurence of Rachiplusia nu (Guenée) (Lepidoptera: Noctuidae) in Smoke (Nicotiana tabacum L.) in Rio Grande do Sul, Brazil," Neotrop. Entomol., vol. 35, no. 5, pp. 705 - 706, Sep-Oct. 2006.) DOI: 10.1590/S1519-566X2006000500020

11. R. I. Neumann, Anuário brasileiro do fumo, Santa Cruz do Sul, Brasil: Editora Gazeta, 200o. (R. I. Neumann, Brazilian Tobacco Yearbook, Santa Cruz do Sul, Brazil: Editora Gazeta, 2000.)

12. S. Oga, Fundamentos de Toxicologia, 2. ed., São Paulo, Brasil: Atheneu, 2003. (S. Oga, Fundamentals of Toxicology, 2nd ed., Sao Paulo, Brazil: Atheneu, 2003.)
13. P. Atkins, L. Jones, "Os elementos," em Princípios de química, Porto Alegre, Brasil: Bookman, 2001, cap. 15-16, pp. 79 - 213. (P. Atkins, L. Jones, "The elements," in Principles of Chemistry, Porto Alegre, Brazil: Bookman, 2001, ch. 15-16, pp. $79-213$.) Retrieved from: https://pt.slideshare.net/CinaraTanhoteSousa/atkinsjones-princpios-de-qumica-questionando-a-vidamoderna-e-o-meio-ambiente

Retrieved on: Jun. 19, 2018

14. C. P. Florêncio, E. Ribeiro Filho, "Geoquímica do bromo em halitas da sub-bacia evaporítica de Maceió," Rev. Geol., vol. 11, pp. 5 - 14, 1998. (C. P. Florêncio, E. Ribeiro Filho, "Geochemistry of bromine in halites from Maceió sub-basin,” Rev. Geol., vol. 11, pp. 5 - 14 1998.)

Retrieved from: http://www.repositorio.ufc.br/bitstrea $\underline{m} /$ riufc/14990/1/1998 art cpflorencio.pdf Retrieved on: Jun. 15, 2018

15. I. Athié et al., "Resistência à fosfina de insetos de grãos armazenados determinada por cromatografia gasosa," Braz. J. Food Technol., no. 57, p. 43, 2001. (] I. Athié et al., "Phosphate resistance of healthy grain insects by gas chromatography," Braz. J. Food Technol., no. 57, p. 43,2001 .)

16. L. M. Lagos, "Methyl bromide, brief description of its toxicology as a basis for occupational health surveillance," Ciência \& Trabajo, no. 26, pp. 182 - 185, 2007.

Retrieved from: https://docplayer.es/82757121Editorial-plaguicidas-a-paso-lento-editorial-cienciatrabajo.html

Retrieved on: Jun. 19, 2018

17. R. D. Arasasingham, T. C. Bruice, "Reaction of hydroxide Ion with manganese(III) tetramesitylporphyrin and the oxidation states of manganese tetramesitylporphyrins," J. Biol. Inorganic Chem., vol. 29, no. 7, pp. 1422 - 1427, Apr. 1990. DOI: $10.1021 /$ icoo332ao28

18. S. M. D. Erthal, "Síntese e caracterização de compostos de coordenação de ferro e manganês como modelos bioinorgânicos," Tese de Doutorado, Universidade Federal de Santa Catarina, Florianópolis, Brasil, 1994. (S. M. D. Erthal, "Sythesis and characterization of iron and manganese coordination compounds as bioinorganic models," Ph.D. dissertation, Federal University of Santa Catarina, Florianópolis, Brazil, 1994.)

19. D.J. Eatough et al., "Chemical composition of environmental tobacco smoke. 1. Gas-Phase acids and bases," Environ. Sci. Technol., vol. 23, no. 6, pp. $679-687$, Jun. 1989 .

DOI: 10.1021/esooo64aoo6

20. V. E. Etges, "Ensaio - O impacto da cultura do tabaco no ecossistema e na saúde humana," Textual, vol. 1 , no. 1, 2002. (V.E. Etges, "Essay - The impact of tobacco growing on the ecosystem and on human health," Textual, vol. 1, no. 1, 2002.)

21. S. Rath et al., "Antimoniais empregados no tratamento de leishmaniose," Quím. Nova, vol. 26, no. 4, pp. 550 - 555, Jul-Ago. 2003. (S. Rath et al., "Antimony agents used in the treatment of leishmaniasis," Quím. Nova, vol. 26, no. 4, pp. 550 - 555, Jul-Aug. 2003.) DOI: $10.1590 /$ So100-40422003000400018

22. B. J. B. Nyarko, E. H. K. Akaho, Y. Serfor-Arman, "Application of NAA standardization methods using a low power research reactor," J. Radioanal. Nucl. Chem. vol. 257, no. 2, pp. $361-366$, Aug. 2003. DOI: $10.1023 / \mathrm{A}: 1024744131848$

23. S. Roth et al., "Determination of $\mathrm{k}_{0^{-}}$and $\mathrm{Q}_{0^{-}}$factor of short-lived nuclides," J. Radioanal. Nucl. Chem, vol. 169, no. 1, pp. $159-175$, Mar. 1993. DOI: $10.1007 / \mathrm{BFO} 2046791$ 
T.M. Filho, et al., Determining Heavy Metals In Nicotiana Tabacum Solanaceae, RAD Conf. Proc., vol. 3, 2018, 174-180

24. N. F. Matheus, "Determinação de metais em Eucalyptus grandis, adubado com biossólido, utilizando a técnica de Análise por Ativação com Nêutrons," dissertação de maestrado, Universidade Cruzeiro do Sul, São Paulo, Brasil, 2007. (N. F. Matheus, "Determination of metals in Eucaliptus grandis, fertilized with biosolid, using a thechnique of
Analysis by Activation with Neutrons," M.Sc. dissertation, University Cruzeiro do Sul, Sao Paulo, Brazil, 2007.)

25. G. F. Knoll, Radiation detection and measurement, 2nd ed., Hoboken (NJ), USA: John Wiley \& Sons. 1986. 